\title{
An Assessment of Land Use/Land Cover Changes in a Section of Niger Delta, Nigeria
}

\author{
Idowu Innocent Abbas
}

Department of Geography, Ahmadu Bello University, Zaria, Nigeria

\begin{abstract}
Remote Sensing and GIS offer quick and efficient approach to the classification and mapping of land use/land cover changes over space and time. Information on changes in resource classes, direction, area and pattern of land use-land cover classes form the basis for future planning. Specifically, the land use/land cover types for the years 1986 and 2008 were studied and compared. The data products used in the study are Landsat TM imagery of 1986 and Nigeriasat-1 imagery of 2008. The data sets were put into Arcview GIS environment for geo-referencing and on-screen digitization of the needed layers. The land use-land cover layers for 1986 and 2008 were therefore generated. The magnitude, trend and annual rate of change analysis were generated from the land use-land covers for the years-1986 and 2008. The annual rate of change was then used as the basis for the projection of the 2050 land use-land cover situation of the study area. The findings show that there was high rate of land use-land cover change leading to decimation of sources of livelihood and resettlement of the people.
\end{abstract}

Keywords GIS, Imageries, Land Cover, Land Use, Remote Sensing

\section{Introduction}

Land use-land cover change analysis enable planners and policy makers to have adequate knowledge on what should be done to have equitable development that will be sustainable and eco-friendly[1]. Land which is the ultimate resource of the biosphere refers to a specific area of the earth surface with physical entity encompassing its topography and spatial nature[2]. It is one of the characteristics of space that is significant for planning and management purposes [3]. Land cover refers to the physical cover on the land including both the natural and modified vegetation and artificial constructions [4]. Land use describes the use of the land by the people usually with emphasis on the functional role of land in economic activities[3]; and man's activities which are directly related to the land[5].

When Land use and land cover are treated jointly, they represent both the physical cover and human imprints on the land. Land use/land cover change represents the changes that are occurring over the cover as a result of human modification of its uses. It can also result from human driven natural processes such as climate change. Land use/land cover change can alter the terrestrial ecosystem and its ability to perform its provisioning and support services[6]. It has the potential to modify the presence and distribution of

*Corresponding author

innoabbas@yahoo.com (Idowu Innocent Abbas)

Published online at http://journal.sapub.org/fs

Copyright (C) 2012 Scientific \& Academic Publishing. All Rights Reserved specific ecosystems and species[7]. When unchecked, change in land use/land cover can lead to land degradation with potential to significantly exacerbate disasters [8].

The Mahin transgressive coast in the western Niger Delta of Nigeria (the study area) is associated with a high intensity of both oil mineral exploration and subsistence farming activities which is leading to changes in the pattern of land use/land cover of the area[9].[10] noted that expansion in oil exploitation has increased the incidence of oil spills which impact the natural ecosystems. Records from[11] suggest that $77 \%$ of oil spills into the Niger delta environment in Nigeria between 1976 and 1996 was not recovered. The processes involved in oil exploration and transportation in the swamp and mangrove ecosystems degrade the land cover and deplete aquatic fauna in a number of localities[12].

[13] asserted that canalisation resulting from attempts by oil companies to construct canals to shorten travel time and improve access to production facilities has caused saltwater intrusion into freshwater zones, and destroyed ecological systems. The increased accessibility resulting from canalization also aggravates illegal logging activities with adverse environmental consequences. The canals have also provided access for water hyacinth to invade swamps and waterways and so impede navigation. All these factors drive land use/land cover change in the Mahin transgressive coastline.

The aim of the study therefore is to assess land use-land cover changes in the Mahin transgressive coast of the western Niger Delta region. The specific object ives are:

(i). to establish the land use/land cover patterns of the 
study area in 1986 and 2008 using multi-date satellite imageries.

(ii). to analyze land use/land cover magnitude and trend of changes in land use/land cover for the area between 1986 and 2008.

(iii). to project the land use/ land cover pattern for the year 2050 using the 1986-2008 scenario as the basis .

The study area lies approximately between latitudes $5^{0} 45^{1}$ and $6^{\circ} 30^{1}$ north of the Equator and longitudes $4^{0} 30^{1}$ and $5^{0} 07^{1}$ East of the Greenwich. It covers about $3,310 \mathrm{~km}^{2}$ and it covers about $88 \mathrm{~km}$ a long the coastline. The distance from the coast inland-wards is about $50 \mathrm{~km}$ at the farthest and about $19 \mathrm{~km}$ at the shortest.

\section{Materials and Methods}

The Landsat imagery of 1986 was downloaded from the website of the Global Land Cover Facility (GLCF) of the University of Maryland, USA[14]. The imagery was used to generate the land use/land cover for 1986.

The Nigeriasat-1 imagery of 2008 was acquired from National Space Research and Development Agency (NASRDA), Abuja. It has 3 spectral bands with spatial resolution of $32 \mathrm{~m}$ on all the bands. The re-sampled Nigeriasat-1 image was interpreted to generate the static land use /land cover data for 2008 .

The images were georeferenced to UTM-31 projection, WGS84 datum and corrected for geometric and radiometric errors from the sources. These data were analyzed using Geographic Information System. Arc view 3.2 GIS software was used for the Interpretation of the Landsat and Nigeriasat-1 satellite imageries that yielded the first set of results which were Land use/land cover data for the years 1986 and 2008 respectively. Field check was conducted using a handheld Garmin S76 Global Positioning Systems (GPS) and digital camera. A total of 185 field checkpoints were established by GPS for accuracy check. According to[12], the ideal nu mber of check points required to be tested in the land use classification map is determined from the binomial probability given in equation 1 as

$$
\mathrm{N}=4(\mathrm{p})(\mathrm{q} \sim) / \mathrm{e}^{2}
$$

Where: $\mathrm{N}=$ is the number of points required,

$\mathrm{p}=$ is the expected percent accuracy

$\mathrm{q} \sim=$ the difference between 100 and $\mathrm{p}$

$\mathrm{e}=$ is the maximu mallowable error

For an expected $90 \%$ accuracy and allowable error of 5\%, the minimu mu mber of points required was 144 . This shows that the number of checkpoints (185) established on the field was far higher than the ideal nu mber of checkpoints required. The checkpoints (stored as GPS waypoints) were downloaded using the Easy GPS program. The coordinates (together with descriptions) were imported into Arcview 3.2 GIS and added to the GIS database as an event theme which was converted into a data layer. This theme of field coordinates was then used as a base for assessing accuracy of the interpreted imageries as described by[15]. Observations of land use-land cover characteristics and human imprints were also made and recorded for verification of the Nigeriasat-1 image features.

The first set of results -land use-land cover data of 1986 that was generated from Landsat TM (1986) and land use land cover of 2008 that was generated from Nigeriasat-1 (2008) within the Arcview GIS environment (as shown in table 1) produced the change statistics in table 2 . The change analysis was performed by intersecting the different multi-temporal land use and land cover layers of 1986 and 2008. The overlay of the land use/land cover statistics assisted in identifying the magnitude, trend and rate of change between 1986 and 2008.

The magnitude of change for each land use/land cover class was calculated by subtracting the area coverage of the second year from that of the initial year as shown in equation 2 .

Magnitude $=$ Magnitude of the new year - Magnitude of the previous year 2

Percentage change (trend) for each LULC type was then calculated by dividing magnitude change by sum of changes between the years concerned and mu ltip lied by 100 as shown in equation 3.

$$
\text { Trend }=\frac{\text { magnitude of change }}{\text { Sum of change }} * 100
$$

In obtaining the annual rate of change for each LULC type, the trend (percentage change) was divided by 100 and mu ltip lied by the nu mber of study year 1986 - 2008 (22years) as shown in equation 4 .

$$
\text { Annual rate of change }=\frac{\text { Trend }}{100} * 22
$$

\section{Results and Discussion}

\subsection{Land Use-Land Cover Statistics for 1986 and 2008}

The static LULC statistics for the study area in 1986 and 2008 is presented in table 1 . It shows both the primary and the secondary classes' area coverage in hectares and their percentages. Figure 1 shows the graphical display of the trend between 1986 and 2008 LULC. The map representations for 1986 and 2008 are shown in figures 2 and 3 respectively.

The primary LULC classes increased from seven in 1986 to eight in 2008 because cloud was discovered in the Nigeriasat-1 imagery of 2008 and was treated as a cover class for the purposes of statistics generation though it was not actually a land use land cover. The specific classes (level II classes) increased from 16 in 1986 to 20 in 2008 with the addition of cloud cover. In specific terms, additional new level II classes including burrow pit/excavated lands, dredged spoil, mud and cloud cover emerged in 2008; while dredge river canal, submerged areas, bare surface and de-vegetated lands increased in extent. The built up area had increased in 2008 to 7934.11 ha (2.18\%) due to massive construction works by Niger Delta Development Commission (NDDC) and most especially Ondo State Oil 
Producing Areas Development Commission (OSOPADEC) [16].

The area covered by the river increased to 9478.01ha (2.60\%), lake/pond had disappeared from the study area, dredged river/canal decreased to 1654.02 (0.54\%) bringing the total water bodies' area to 11432.03 ha $(5.32 \%)$. The degraded lands increased to 78111.74ha (25.81\%) with the specific levels being submerged areas 40870.14ha (11.23\%), burrow pit/excavated land being 246.60ha (0.07\%), bare surfaces being 35244.96ha (9.69\%) and Devegetated areas being 17552.78 ha $(4.82 \%)$. The wetlands area decreased to 14562.16ha (4.0\%) with specific classes of marsh being 3010.17ha (0.83\%) and mangrove being 11551.99ha (3.17\%).

Table 1. LULC Statistics for 1986 and 2008

\begin{tabular}{|c|c|c|c|c|c|}
\hline Primary Class & Secondary Class & $\begin{array}{c}\text { Area (Ha) } \\
2008\end{array}$ & $\begin{array}{c}\text { Percent } \\
2008\end{array}$ & $\begin{array}{c}\text { Area (Ha) } \\
1986\end{array}$ & $\begin{array}{c}\text { Percent } \\
1986\end{array}$ \\
\hline Built-Up Areas & Built Up Area & 7934.11 & 2.39 & $4,976.13$ & 1.5 \\
\hline $\begin{array}{c}\text { Water bodies } \\
\text { Total }\end{array}$ & $\begin{array}{c}\text { River } \\
\text { Lake/Pond } \\
\text { Dredged River/Canal }\end{array}$ & $\begin{array}{c}9478.01 \\
0.0 \\
1954.02 \\
11432.03 \\
\end{array}$ & $\begin{array}{c}2.87 \\
0 \\
0.59 \\
3.36\end{array}$ & $\begin{array}{c}8,870.26 \\
595.25 \\
1,873.17 \\
14,314.68 \\
\end{array}$ & $\begin{array}{l}2.7 \\
0.2 \\
0.6 \\
3.5\end{array}$ \\
\hline $\begin{array}{c}\text { Degraded Lands } \\
\text { Total }\end{array}$ & $\begin{array}{c}\text { Submerged Areas } \\
\text { Burrow Pit/Excavated } \\
\text { Land } \\
\text { Bare Surfaces } \\
\text { Devegetated Areas }\end{array}$ & $\begin{array}{c}40870.14 \\
534.60 \\
35244.96 \\
17552.78 \\
94202.48\end{array}$ & $\begin{array}{c}12.35 \\
0.16 \\
10.65 \\
5.30 \\
28.46\end{array}$ & $\begin{array}{c}3,887.59 \\
0 \\
5,473.49 \\
12272.66 \\
21633.74\end{array}$ & $\begin{array}{c}1.2 \\
0 \\
1.7 \\
3.7 \\
6.6\end{array}$ \\
\hline $\begin{array}{c}\text { Wetlands } \\
\text { Total }\end{array}$ & $\begin{array}{c}\text { Marsh } \\
\text { Mangrove }\end{array}$ & $\begin{array}{c}3010.17 \\
11551.99 \\
14562.16 \\
\end{array}$ & $\begin{array}{c}0.90 \\
3.50 \\
4.4 \\
\end{array}$ & $\begin{array}{c}25,384.62 \\
8,175.05 \\
33,559.67 \\
\end{array}$ & $\begin{array}{c}7.7 \\
2.5 \\
10.2 \\
\end{array}$ \\
\hline $\begin{array}{l}\text { Agricultural Lands } \\
\text { Total }\end{array}$ & $\begin{array}{l}\text { Farmland/Fallow } \\
\text { Plantation }\end{array}$ & $\begin{array}{c}56935.41 \\
108.03 \\
57043.44\end{array}$ & $\begin{array}{c}17.21 \\
0.03 \\
17.24\end{array}$ & $\begin{array}{c}79,209.86 \\
2,105.71 \\
81,315.57\end{array}$ & $\begin{array}{c}24 \\
0.6 \\
24.6\end{array}$ \\
\hline $\begin{array}{c}\text { Nat ural/Semi Natural } \\
\text { Vegetation } \\
\text { Total }\end{array}$ & $\begin{array}{c}\text { Heavy Forest } \\
\text { Light forest/Thicket } \\
\text { Palm Swamp } \\
\text { Scrub / Grassland }\end{array}$ & $\begin{array}{c}75579.1 \\
29056.31 \\
29882.71 \\
8885.19 \\
144249.91 \\
\end{array}$ & $\begin{array}{c}22.84 \\
8.80 \\
9.04 \\
2.44 \\
43.81 \\
\end{array}$ & $\begin{array}{c}82,434.50 \\
44,091.93 \\
41,868.34 \\
11,114.99 \\
179,509.76 \\
\end{array}$ & $\begin{array}{c}24.9 \\
13.3 \\
12.7 \\
3.4 \\
54.3 \\
\end{array}$ \\
\hline $\begin{array}{c}\text { Open Area } \\
\text { Total } \\
\end{array}$ & $\begin{array}{l}\text { Sandbar } \\
\text { Dredged Spoil } \\
\text { Mud }\end{array}$ & $\begin{array}{c}1464.31 \\
201.27 \\
45.08 \\
1710.66 \\
\end{array}$ & $\begin{array}{l}0.44 \\
0.06 \\
0.01 \\
0.52 \\
\end{array}$ & $\begin{array}{c}484.68 \\
0 \\
0 \\
484.68 \\
\end{array}$ & $\begin{array}{c}0.1 \\
0 \\
0 \\
0.1\end{array}$ \\
\hline $\begin{array}{l}\text { Cloud } \\
\text { Total } \\
\end{array}$ & Cloud cover & $\begin{array}{l}329.64 \\
329.64 \\
\end{array}$ & $\begin{array}{l}0.10 \\
010 \\
\end{array}$ & - & $\begin{array}{l}- \\
-\end{array}$ \\
\hline Ground Total & & 331464.43 & 100 & 331465.23 & 100 \\
\hline
\end{tabular}

Source: modified from[17] with GIS analysis carried out by the author

LULC 1986 and 2008

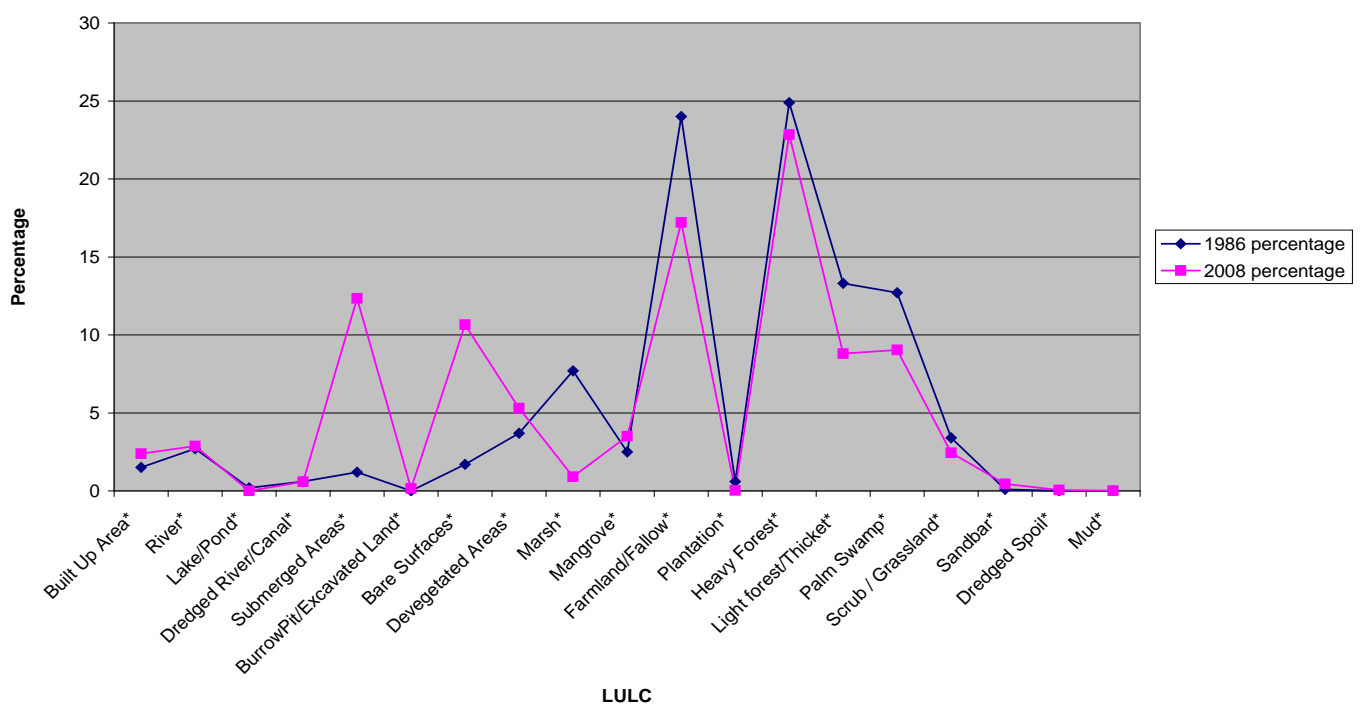

Figure 1. LULC for 1986 and 2008 


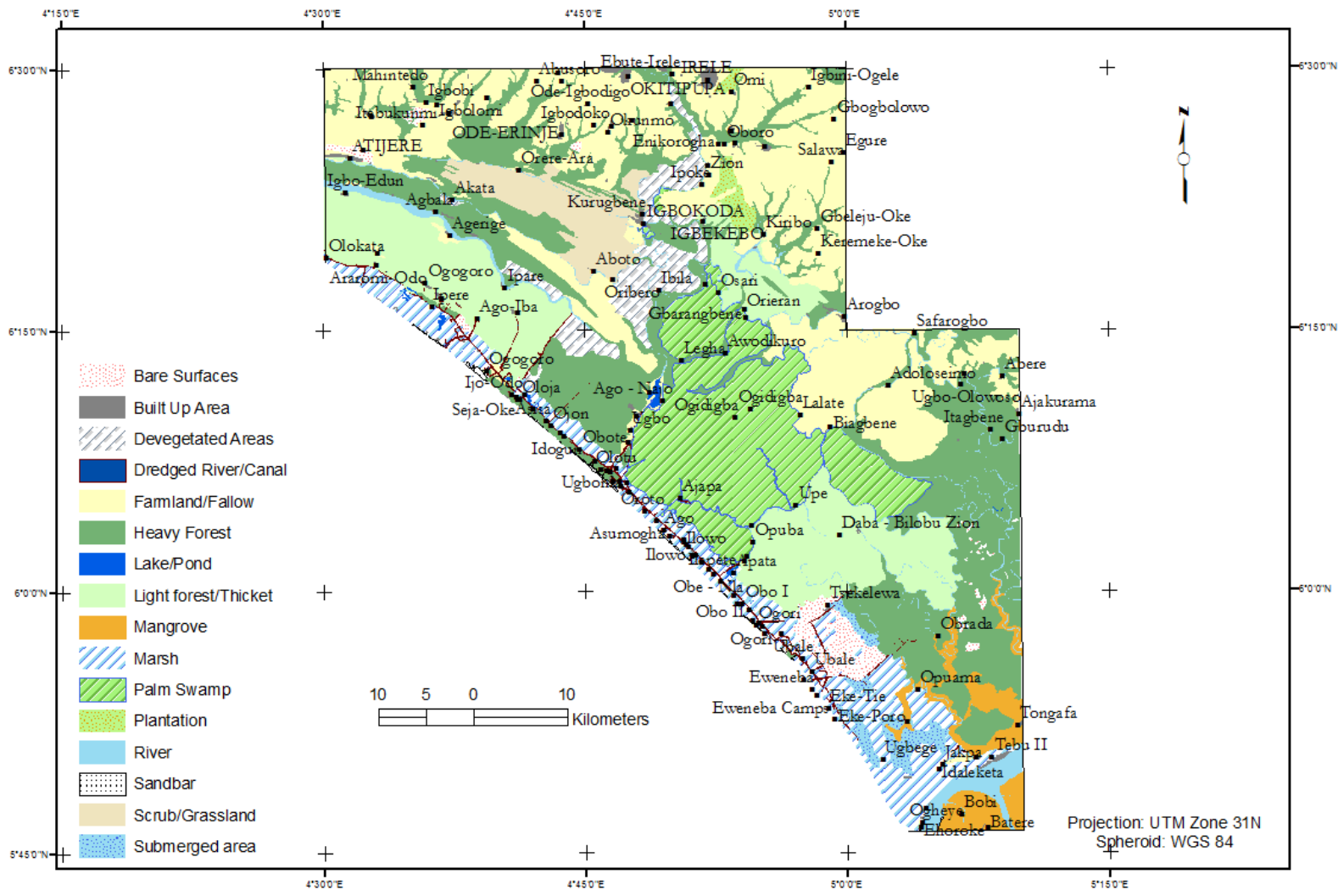

Figure 2. Land use-land cover map for 1986

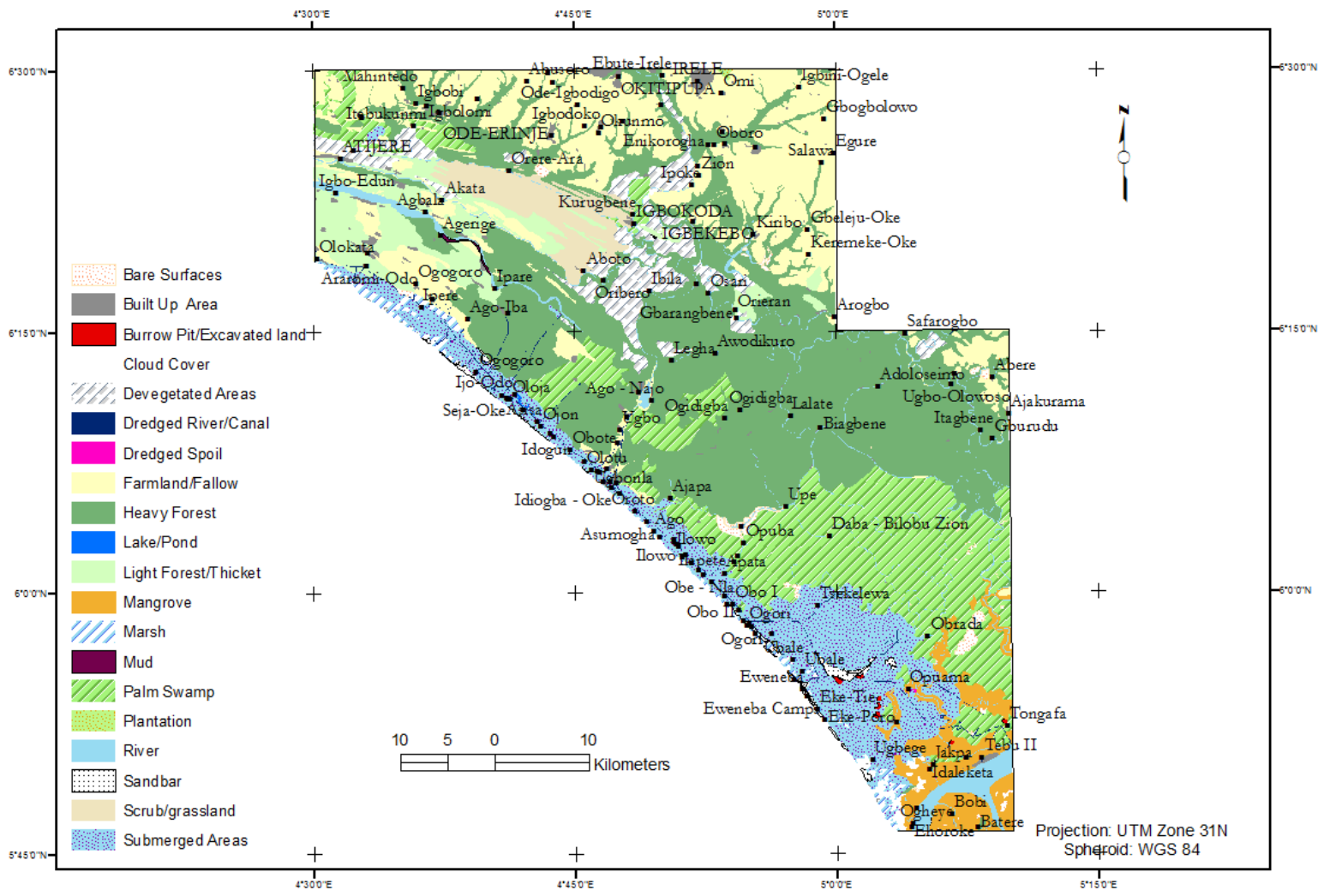

Figure 3. Land use-land cover map for 2008 
Table 2. 1986-2008 change magnitude, trend and annual rate

\begin{tabular}{|c|c|c|c|c|}
\hline \multirow{2}{*}{ Primary Class } & \multirow{2}{*}{ Secondary Class } & \multicolumn{3}{|c|}{ 1986-2008 change } \\
\hline & & Magnitude (Ha) & Trend & Annual Change rate \\
\hline Built-Up Areas & Built Up Area & 2957.98 & 22.9 & 5.04 \\
\hline Waterbodies & $\begin{array}{c}\text { River } \\
\text { Lake/Pond } \\
\text { Dredged river/Canal }\end{array}$ & $\begin{array}{l}607.63 \\
-595.25 \\
80.94\end{array}$ & $\begin{array}{r}3.31 \\
-100 \\
2.11\end{array}$ & $\begin{array}{l}0.73 \\
-22 \\
0.47\end{array}$ \\
\hline Degraded Lands & $\begin{array}{c}\text { Submerged Areas } \\
\text { Burrow Pit/Excavated Land } \\
\text { Bare Surfaces } \\
\text { Devegetated Areas }\end{array}$ & $\begin{array}{c}36982.66 \\
534.60 \\
29771-7 \\
5280.12\end{array}$ & $\begin{array}{r}82.63 \\
100 \\
73.12 \\
17.70\end{array}$ & $\begin{array}{r}18.18 \\
22 \\
16.09 \\
3.89\end{array}$ \\
\hline Wetlands & $\begin{array}{c}\text { Marsh } \\
\text { Mangrove }\end{array}$ & $\begin{array}{c}-22374.63 \\
3376.86 \\
\end{array}$ & $\begin{array}{c}-78.80 \\
17.12 \\
\end{array}$ & $\begin{array}{c}-17.33 \\
3.77 \\
\end{array}$ \\
\hline Agricultural Lands & $\begin{array}{c}\text { Farmland/Fallow } \\
\text { Plantation } \\
\end{array}$ & $\begin{array}{l}-22274.78 \\
-1997.69 \\
\end{array}$ & $\begin{array}{l}-16.35 \\
-90.24 \\
\end{array}$ & $\begin{array}{r}-3.60 \\
-19.85 \\
\end{array}$ \\
\hline $\begin{array}{c}\text { Natural/ Semi Natural } \\
\text { Vegetation }\end{array}$ & $\begin{array}{c}\text { Heavy Forest } \\
\text { Light forest/Thickest } \\
\text { Palm Swamp } \\
\text { Scrub / Grassland } \\
\end{array}$ & $\begin{array}{c}-6009.06 \\
-15812.03 \\
-11985.63 \\
2229.97 \\
\end{array}$ & $\begin{array}{l}-3.78 \\
-21.61 \\
-16.70 \\
-11.15 \\
\end{array}$ & $\begin{array}{l}-0.83 \\
-4.75 \\
-3.67 \\
-2.45 \\
\end{array}$ \\
\hline Open Area & $\begin{array}{c}\text { Sandbar } \\
\text { Dredged Spoil } \\
\text { Mud }\end{array}$ & $\begin{array}{c}979.52 \\
201 \\
45\end{array}$ & $\begin{array}{c}50.27 \\
100 \\
100\end{array}$ & $\begin{array}{l}11.06 \\
22 \\
22\end{array}$ \\
\hline
\end{tabular}

The agricultural lands also decreased to 57043.44ha (15.68\%) with the level II classes of farmland/fallow being 56935.41ha (15.65\%) and plantation being 108.03ha $(0.03 \%)$. The natural/semi natural primary class experienced further decline in 2008. The total extent of the natural/semi natural primary class was 144249.91ha (48.72\%) in 2008. The coverage of the primary classes are; heavy forest 76425.70ha (30.09\%), light forest/thicket 29056.31ha (7.98\%), palm swamp 29882.71ha (8.21\%) and scrub/grasslands 8885.19ha (2.44\%). The open area increased from 1 level II class to 3 level II class in 2008 with total area of $1710.66 \mathrm{ha}(0.47 \%)$ with specific coverage of sandbar being 1464.31ha (0.4\%), dredged spoil being 201.27ha $(0.06 \%)$ and mud being 45.08ha $(0.01 \%)$. The cloud cover took $329.64 \mathrm{ha}(0.10 \%)$ of the area coverage thus increasing the total land mass of the study area to 330, 846.79ha higher than the previous 330, 517.15ha in 1960 and in 1986 .

\subsection{Magnitude, Trend (Percentage Change) and Annual Rate of Change (1960-2008)}

The change magnitude, percentage (trend) and annual rate of change between 1986 and 2008 is presented in table 2 .

The period 1986 - 2008 witnessed the emergence of degraded lands. The gains of existing classes reduced while their loss es to the degraded lands increased. Correspondingly, the gain of the newer land cover classes increased substantially. Burrows pit/excavated land (100\%), submerged areas (82.63\%) and bare surfaces (73.12\%) which are 2 of the newer classes recorded the highest gains between 1986 and 2008. Sand bar (50.27\%) and built up areas $(22.9 \%)$ also recorded high gains. Others classes that gained include river (3.31\%), dredged river canal $(2.11 \%)$, mangrove (3.77\%) and devegetated areas (4.11\%).

In summary, 8 of the 19 classes of 1986 recorded loss. These are lake/pond (22\%), marsh (17.33\%), plantation (19.85\%), light forest/thicket (4.75\%), palm swamp (3.67\%), scrub/grassland (2.45\%), farmland/fallow (3.6\%) and heavy forest $(0.83 \%)$.

\subsection{Land Use- Land Cover Projection for the Year 2050}

The land use land cover projection for the year 2050 was calculated based on the scenario of change between 1986 and 2008. The annual rate of change between 1986 and 2008 was used to multiply the difference in the years (2050-2008=42 years). This is done for all the classes and the resultant result is added to the present land use-land cover coverage for 2008. The projected figure is therefore presented in table 3.

From table 3, if the scenario between 1986 and 2008 is maintained, there is the possibility that by the year 2050, the percentage of built up area would have increased from $2.39 \%$ in 2008 to $2.5 \%$, degraded ecologies from $31.47 \%$ in 2008 to $38.69 \%$ in 2050 , natural/semi natural vegetation from $43.81 \%$ in 2008 to $42.99 \%$ in 2050 , agricultural lands from $17.24 \%$ in 2008 to $16.98 \%$, wetlands from $4.4 \%$ in 2008 to $4.09 \%$ by the year 2050, degraded lands from $28.38 \%$ in 2008 to $28.85 \%$ in 2050 and water bodies from $3.36 \%$ in 2008 to $3.43 \%$ in 2050 . The built up area, water bodies, degraded lands and open area will increase giving the present land use land cover scenario while natural and semi natural vegetation, wetlands agricultural lands will decrease by the year 2050 . 
Table 3. Land use land cover projection for 2050

\begin{tabular}{|c|c|c|c|c|}
\hline $\mathrm{S} / \mathrm{NO}$ & Primary class & Secondary class & Area (Ha) & $\%$ \\
\hline 1. & Built up area & Built up area & 8145.79 & 2.50 \\
\hline 2 & Water bodies & $\begin{array}{c}\text { River } \\
\text { Lake/pond } \\
\text { Dredged river/canal } \\
\text { Total }\end{array}$ & $\begin{array}{c}9508.67 \\
0 \\
1973.76 \\
11482.43\end{array}$ & $\begin{array}{c}2.84 \\
0 \\
0.59 \\
3.43\end{array}$ \\
\hline 3 & Degraded lands & $\begin{array}{c}\text { Submerged areas } \\
\text { Burrow pit/excavated land } \\
\text { Bare surfaces } \\
\text { Devegetated areas } \\
\text { Total }\end{array}$ & $\begin{array}{c}41633.7 \\
1458.60 \\
35920.74 \\
17716.16 \\
96729.20 \\
\end{array}$ & $\begin{array}{r}12.45 \\
\\
0.35 \\
10.74 \\
5.31 \\
28.85 \\
\end{array}$ \\
\hline 4 & Wetlands & $\begin{array}{c}\text { Marsh } \\
\text { Mangrove } \\
\text { Total }\end{array}$ & $\begin{array}{c}2282.31 \\
11710.33 \\
13992.64\end{array}$ & $\begin{array}{l}0.68 \\
3.41 \\
4.09\end{array}$ \\
\hline 5 & Agricultural lands & $\begin{array}{c}\text { Farmland/fallow } \\
\text { Plantation } \\
\text { Total }\end{array}$ & $\begin{array}{c}56784.21 \\
0 \\
56784.21\end{array}$ & $\begin{array}{c}16.98 \\
0 \\
16.98\end{array}$ \\
\hline 6 & Nat ural/semi-nat ural veget at ion & $\begin{array}{c}\text { Heavy forest } \\
\text { Light forest/thicket } \\
\text { Palm swamp } \\
\text { Scrub/grassland } \\
\text { Total }\end{array}$ & $\begin{array}{c}75544.24 \\
28856.81 \\
29728.57 \\
8782.29 \\
142911.91\end{array}$ & $\begin{array}{r}32.73 \\
3.69 \\
3.95 \\
2.62 \\
42.99\end{array}$ \\
\hline 7 & Open area & $\begin{array}{c}\text { Sandbar } \\
\text { Dredged spoil } \\
\text { Mud } \\
\text { Total } \\
\end{array}$ & $\begin{array}{c}1928.83 \\
1125.27 \\
969.08 \\
4023 \\
\end{array}$ & $\begin{array}{l}0.58 \\
0.34 \\
0.29 \\
1.21 \\
\end{array}$ \\
\hline & & Grand Total & 334069.18 & 100.05 \\
\hline
\end{tabular}

Source: GIS Analysis

Specifically, plantation agriculture would have disappeared by the year 2050 and the pose serious threat to food security and human survival. The degraded ecologies would have increased in size from $31.47 \%$ in 2008 to 38.69\% by the year 2050. This calls for serious management of the ecosystem of the study area especially with the increase in the displacement of the people from their settlements and uproots of livelihoods such as agriculture especially fishing and crop production.

\section{Conclusions}

Findings in the study of an area of about 331,000 hectares have shown a significant spatio-temporal variation in the rate of gain and loss amongst the different land use-land cover categories. But of utmost relevance is the near complete loss of the region's ecological biodiversity.

The commencement of oil and gas exploration and exploitation, has brought environmental problems associated with canalization, oil spillage, gas flares, land subsidence, depletion of forest resources, riverbank and coastal erosion, and so on. There are indications that the extraction of large quantities of oil and gas from the region is continuing to cause subsidence and relocation of settlements.

This is most disturbing especially as sources of livelihoods in the form of farming and fishing which are the major occupations in the area are threatened. The survival of the inhabitants now hang in the balance and if drastic measures are not taken to check the high rate of land use- land cover change been witnessed the study area might witness restiveness as is currently going on in both the central and eastern Niger Delta.

On the basis of this study, it is highly recommended that all dredged canals and constructed water channels that opened directly from the land to the sea should be managed in such a way to prevent continued saline water inflow into the land areas

There is the need for urgent land resources restoration for areas that have suffered terrible degradation. In particular, the stretch of coastal land that runs along the ocean coast. Mangrove and marsh replant needs to be urgently considered.

Legislations compelling environmental protection, restoration and remediation should be enforced to stem externalities resulting from resource exploitation; oil companies' and other companies in the area should be environment-friendly in their activities and respect all laws on environmental protection and sustainability as exp ressed by[18].

The study area environment is no doubt under siege, and unless both short and long-term changes are instigated, sustainable development may rema in an illusion. There is no doubt that there is need for balanced approach towards 
sustainable development and environmental sustainability especially if the amnesty programme of the Federal Government of Nigeria is to be successful.

\section{ACKNOWLEDGEMENTS}

The authors wish to acknowledge Prof. E.O Iguisi for his guidance in carrying out this study. The managements of GLCF and NASRDA are also appreciated. Thanks also go to the people of the study area for their support throughout the study.

\section{REFERENCES}

[1] Abbas, I.I and Fasona, M.J (2012): Remote Sensing and Geographic Information Techniques: Veritable Tools for Land Degradation Assessment, American Journal of Geographic Information System 2012, 1(1): 1-6 DOI: 10.5923/j.ajgis.20120101.01

[2] Ashaye TI (1987) Land and soil characteristics studies in relation to erosion and Livelihood with special reference to river basin development, Sagua VO, Enabor EE, Ofomata GEK, Ologe KO and Oy ebande LO (eds) Ecological Disasters in Nigeria: Soil Erosion, FMST, Lagos pp173.

[3] Anderson JR, Hardy EE, Roach JT and Witmer RE (1976) A Land use and Land covers Classification System for use with Remotely Sensed Data. Geological Survey Professional Paper 964, Washington.D.C

[4] Campbell JB (1996) Introduction to Remote Sensing, The Guilford Press

[5] Abdukadir, A. (1993): Remote Sensing and Land Degradation. Nigerian Journal of Remote Sensing, Vol. 1(1), pp 65-72

[6] Fischlin, A., G.F. Midgley, J.T. Price, R. Leemans, B. Gopal, C. Turley, M.D.A. Rounsevell, O.P. Dube, J. Tarazona, A.A. Velichko, 2007: Ecosystems, their properties, goods, and services. Climate Change 2007: Impacts, Adaptation and Vulnerability. Contribution of Working Group II to the Fourth Assessment Report of the Intergovernmental Panel on Climate Change, M.L. Parry, O.F. Canziani, J.P. Palutikof, P.J. van der Linden and C.E. Hanson, Eds., Cambridge University Press, Cambridge, UK, 211-272
[7] German Advisory Council on Climate Change (2008): Climate Change as a security risk, Earthscan, U.K

[8] Leary, N, Kulkarni, J and Seipt, C (2007): Assessment of Impacts and Adaptation to Climate Change: Summary of the Final Report of the AIACC Project. A Global Environment Facility Enabling Activity in the Climate Change Focal Area Project No. GFL-2328-2724-4330

[9] Fasona MJ (2003) Coastal Flooding Risk and Community Adaptive Strategies in the Western Niger Delta, Journal of Environment and Behavior, Vol. 1 pp56-62

[10] Federal Environmental Protection Agency (1991) National Policy on The Environment, The Presidency, Abuja, Nigeria, pp43

[11] NSOER (2008) The Nigerian State of Environment Report, SEDEC Associates, Lagos, pp xlvi, 365

[12] Mayowa Fasona, Ademola Omojola and Alabi Soneye (2011): A study of land degradation pattern in the Mahin mud-beach coast of southwest Nigeria with spatial-statistical modelling geostatistics. Journal of Geography and Geology, 3(1), p141-159. ISSN 1916-9779. http://www.ccsenet.org/journal/ index.php/jgg/article/view/7453

[13] Fasona, M.J (2007): Land Degradation and Environmental Change in Ondo State, South-West, Nigeria, An (unpl) PhD thesis, University of Lagos

[14] www.glcf.umiacs.umd.edu

[15] Jensen, J R (1986): Introductory Digital Image Processing - A remote Sensing perspective, Prentice-Hall, N.J, 379p

[16] OSOPADEC (2009): A Compendium of the Commission's Formation and Activities, Ondo State Oil Producing Area Development Commission, Integrity Press Ltd, Akure.

[17] Mayowa FASONA and Ademola OMOJOLA (2009): Land cover change and land degradation in parts of the southwest coast of Nigeria. Afr. J. Ecol., 47 (S1), p30-38, doi.wiley.com/10.1111/j.1365-2028.2008.01047.. http://onlin elibrary.wiley.com/doi/10.1111/j.1365-2028.2008.01047.x/f ull

[18] Abbas, I I (2011): An Assessment of Land use-land cover changes and their implications on land resources and livelihood in a section of the Niger delta region, Nigeria, An (unpl) $\mathrm{PhD}$ thesis, Ahmadu Bello University, Zaria, Nigeria. 